Article

\title{
New Dimensions for Circularity on Campus-Framework for the Application of Circular Principles in Campus Development
}

\author{
Birgit Hopff ${ }^{1, *}$, Steffen Nijhuis ${ }^{2}(1)$ and Leendert A. Verhoef ${ }^{3}$ \\ 1 Independent Researcher, Stadsruim BV, 2613 EB Delft, The Netherlands \\ 2 Faculty of Architecture and the Built Environment, Delft University of Technology, 2628 BL Delft, \\ The Netherlands; S.Nijhuis@tudelft.nl \\ 3 Amsterdam Institute for Advanced Metropolitan Solutions, 1018 JA Amsterdam, The Netherlands; \\ leendert.verhoef@ams-institute.org \\ * Correspondence: mail@hopff.nl; Tel.: +31-612-981-189
}

Received: 29 November 2018; Accepted: 22 January 2019; Published: 24 January 2019

\begin{abstract}
To what extent can transformation and development processes on a university or other campus fit in with the principles of circularity? This paper builds a bridge between the more theoretical approach of the circular economy and daily practice in campus development, using semi-structured in-depth interviews with a broad range of stakeholders in university management in Dutch universities. The study aims to show possible perspectives and offers insight into which factors are important for the sustainable development of a university or other campus, taking into account the principles of the circular economy. The paper introduces a framework for understanding the various dimensions and scales of campus operations. The aim is to make a practical contribution to the implementation of circular principles in campus development. The main conclusions are that circularity is an organisational issue, complexity must be reduced, and integral policy and specialised knowledge are required. Five recommendations towards an integrated strategy for circularity in campus development are given.
\end{abstract}

Keywords: area development; campus development; circularity; circular economy; sustainability

\section{Introduction}

The circular economy is a new field of research and the number of articles has grown rapidly over the past 10 years. These have usually involved establishing a close link between the concepts of the circular economy and sustainability, without this relationship being precisely defined in scientific terms [1]. While energy efficiency issues in the construction sector have been extensively researched, circularity remains a relatively new issue [2]. No clear definitions of the concept of the circular economy' are used in science and literature [3]. Various studies [2,4-6] have shown that circularity is a complex subject with many facets. Scientific studies on the circular economy often focus on the macro scale of a region or city, or on the micro scale of product development $[6,7]$ and individual projects with an experimental character or limited circularity aspects [8].

\subsection{Objective}

To date, there has been no systematic application of circular principles in Dutch campus development. Construction, development and redevelopment projects usually focus on limited aspects of circularity and are separate from each other. In the area of sustainable development of the physical campus, there is a need for the elaboration of practice-oriented strategies for an integrated 
approach. This study establishes a connection between the subjects of a campus environment, area development and the circular economy. The central research question in the research is: To what extent and in what way are principles of the circular economy applied in the area development of (university) campuses in the transformation to a sustainable campus? By looking beyond the boundaries of a single building, structural links and a systematic approach are sought within the campus area. For this study, the Dutch university campuses are studied. The complexity and breadth of the concept of the circular economy pose a major challenge for organisations in terms of structurally applying circularity in existing processes. This paper introduces a framework for understanding the various dimensions and scales of campus operations. It shows which dimensions in the area development of university and other campuses influence the application of circular principles in the transformation to a sustainable campus. In this respect, the study provides insight into:

- How the principles of circularity can be systematically applied in practice in area (and other) development and transformation of a campus;

- What conditions must be met to develop/redevelop a university campus in accordance with the principles of the circular economy.

\subsection{Method}

The application of circular principles is being researched on university campuses in the Netherlands, with a focus on real estate and area development processes, as opposed to facility processes. The paper develops a framework from theory. It validates to what extent the framework works in practice. As such it is not a qualitative study, nor is it grounded in theory. It develops a framework for future research. In the first stage, a literature review is based on scientific literature and practice-based research on the circular economy and campus development to answer research questions. The preliminary research was aimed at finding leading dimensions in campus development that are characteristic of a campus and that influence circularity. These studies have revealed a number of principles that are relevant for campus systems to meet the requirements of circularity. The principles have been filtered according to their significance for the spatial sector and possible applications in campus development.

In terms of area development, the campus can be regarded as a defined system, of which buildings are a part. The system perspective is again seen as an important aspect in the approach to circularity. The aim is to be able to identify structures and processes within the 'campus' system that influence the application of circular principles. The complex relationships between flows and levels of scale, criteria for circularity, development processes and relevant actors are investigated in order to identify the mutual influence. The following factors were related in an analysis matrix (Table S1) with the aim to discover which processes influence circularity and to make possible patterns visible: principles of circularity such as minimizing raw material consumption and waste; value preservation of raw materials, high quality reuse material/product, use of renewable energy sources, minimizing $\mathrm{CO}_{2}$ emissions and toxic substances, climate adaptability, biodiversity and social balance; related to the production process, product design, material selection, disposal process, construction process and assembly, transport and distribution, system design, development process, demand specification, product choice, management process and user behaviour and policy. In the first step of the analysis, the different spatial scales, flows of resources and principles of circularity were linked to development processes which influence the circular principles. To make patterns transparent, three categories were applied in the matrix fields for the different groups of actors and processes, based on the division of [9]:

- The creation process - with the producer, supplier and builder/contractor;

- The design process-with the architect, designer and consultant;

- The development process, management and use-with client, owner, user and manager. 
A more in-depth analysis in the following step also includes more detailed criteria and indicators for circularity such as footprint, efficient land use, building flexibility (multifunctional), dismountable constructions, modular buildings, energy performance, policy reuse, environmental performance and origin of materials and information management, in order to investigate the relationship between the process and circularity principle. By naming these criteria and indicators per flow and per scale level, it is clarified which factors in the process can have an impact. By means of a theoretical analysis, stakeholders such as producers or clients, who exert a special degree of influence on circularity in specific processes, come into the picture. To test the theoretical concepts found earlier in an analytical way, the assumptions derived from the analysis were translated into interview questions. The 13 interviews with various stakeholder groups are used as a means to see how the principles work and whether the problems and conclusions from the theoretical research are also valid in practice.

During the interviews, it was investigated how sustainability aspects and circularity are implemented in the campus developments. The questions focus on the scale level of a specific project, vision and policy, development processes, instruments used and actors involved. Questions were asked about objectives and factors relevant to circularity, to what extent specific criteria are consistently applied in projects with a circular approach, which aspects are missing and why certain factors are not taken into account. The question of where obstacles are experienced in the application of circular principles in campus development was also asked. The interviews were conducted with employees involved in sustainability, procurement and area development at six Dutch universities.

The Netherlands has 13 universities, about half of which are involved in technological research. A representative selection of these universities has been approached. On the campuses, subprojects were investigated, where within the scope of project development, attention was paid in various ways to a possible circular approach with a spread of aspects and factors. Each subproject has a different focus with respect to the development phase, scale and development task.

Given the broad problem definition, the research has an exploratory character. The insights from the theoretical research and the interviews have been translated into a more generic approach and relevant process steps for the structural application of circular principles. The steps which must be taken to systematically apply circularity in campus development and to be able to guarantee it for future developments have been mapped out by means of a framework. The framework provides a structure and overview to apply the principles of circularity in a systematic way. The process of how to integrate the various dimensions and area scale levels is an important aspect of the new knowledge this article delivers.

\section{Building Blocks for a Circular Approach}

\subsection{Evolution of the Concept of the Circular Economy}

The idea of circularity is essentially not new and until the industrial revolution, the economy was predominantly circular [5]. That there are limits to the extent to which human activity can deplete the natural environment and that population growth affects the earth's finite resources was noted by the Club of Rome in its first report [10]. The idea of a circular economy is largely rooted in the concept of cradle-to-cradle [11]. Drawing from the function principle of ecosystems, this design philosophy focuses on optimising systems instead of components to minimise the loss of value of raw materials. The publication 'Towards the Circular Economy. Economic and business rationale for an accelerated transition' by the Ellen MacArthur Foundation [12] is in line with the cradle-to-cradle concept and is considered one of the founders of the circular economy.

There is no unequivocal definition of the term 'circular economy' [3]. There is a close link between the concepts of the circular economy and sustainability [13], but this relationship is not precisely defined in scientific terms [14]. Circularity is seen in some concepts as a prerequisite for sustainability [1]. According to the analysis of Kirchherr et al. [3], the 'Circular Economy' is an economic system based on business models that replace the concept of 'end-of-life' with reducing, reusing and recovering raw 
materials in production, distribution and consumption processes, by operating at different levels of scale and with the aim of achieving sustainable development for present and future generations. Often a link can be found with the three pillars of sustainability: economy, environment and society [6,14].

The circular economy pertains to the careful and sustainable use of existing resources. The principle of cyclical material cycles and their closure remains an important aspect in the different definitions and concepts of the circular economy [15]. In their conclusions, Kirchherr et al. [3] stressed that the circular economy should be seen as a fundamental systemic change. Pauliuk [16] and Preston [17] also referred to the theoretical background of systems theory [18] and the relationship with Industrial Ecology. By involving all stages of life in development and by using products, components and materials within the cycles on a permanent basis, the linear economy becomes a circular economy [8].

\subsection{The Circular Economy in the Spatial Sector}

The spatial sector plays an important role in the circular economy in view of the large flows of raw materials involved. Area development concerns the physical adaptation of a specific location and always takes place in a specific socio-economic context, but transformations within the area also have effects on the external environment and vice versa. The aim of area development is to create 'integral environmental quality' [19]. There is a direct link between the quality of the living environment and sustainability in terms of environmental quality, health issues and social values on the one hand and the future value of spatial quality on the other. In addition to site-specific elements, flows such as water, energy and mobility form part of area development. Wientjes [20] concludes that spatial planning does play a role in making a region circular. Too often the emphasis of the circular economy is on business (and other) processes and the initiative is generally left to companies and citizens, without making a link with the function that spatial planning has in achieving sustainability. To make the circular economy a guiding principle, spatial plans must have a circular approach from the initial phase, otherwise little usually remains of the sustainability ambitions [20].

The circular economy goes beyond recycling and, in order to achieve maximum environmental benefits, strategies that involve the entire production and consumption chain are preferable [21]. In order to achieve maximum economic and ecological effects based on circular principles, sometimes more radical changes and innovations to existing systems are needed. This requires a new way of thinking about designing products and services, adapting production methods, but also concerns procurement processes [8].

In the search for possibilities to make ever-growing cities more sustainable, in recent years, increasing attention has been paid to the concept of 'urban metabolism' [22,23]. The totality of urban flows such as energy, food or waste is considered as a metabolic process of the city organism [24]. Urban metabolism can be defined as "the sum total of technical and socio-economic processes occurring in cities" [22]. It not only relates to internal transformation processes within the urban system itself (the organism), but also to the balance of the inflow and outflow, the exchange with the environment. With a view to sustainable urban development, Tjallingii [25] formulated the Ecopolis strategy: The city is seen as a dynamic and complex ecosystem which consists of a number of smaller ecosystems on the one hand and is itself part of a larger ecosystem on the other hand. Plan development not only concerns the quality of a specific area, but also the inflow and outflow of the system and the quality of the environment outside those areas. Because the management of flows depends on the actors involved, but the flows also influence the design of areas and vice versa, these three areas of attention cannot be seen in isolation [24].

The application of circular principles in the spatial sector is more complex than in product development. Indicators of circularity usually relate to different levels: The micro level of construction (and other) products, the meso level at the local scale with neighbourhoods and the macro level of cities, regions or the whole country [16]. In the built environment, each material has its own specific life cycle and is part of different processes and changing uses over its lifetime [6]. The transition to a 
circular economy in the spatial sector therefore requires different perspectives of scale and a broader view of the dimensions in research and planning.

\subsection{Circular Construction Production}

The demand for materials is high: Around $50 \%$ of the raw materials used in the Netherlands are processed in the construction sector [26]. However, the scarcity of materials is seldom a motive for the circular economy in construction [27]. With around $40 \%$ of all waste in the Netherlands, the sector is responsible for large waste flows and around $35 \%$ of $\mathrm{CO}_{2}$ emissions [26]. In the Netherlands, more than $95 \%$ of construction and demolition waste is recycled [28], usually in a low-grade manner [9]. However, a large proportion of the raw materials leave the chain [9] and there are no closed cycles. New buildings are hardly ever made with recycled products, only $3 \%$ of the raw materials are used in their original function, so the influx of primary raw materials remains high [29]. The energy needed to produce building materials usually comes from fossil sources. The carbon footprint of these materials and the extraction of raw materials for construction lead to pressure on ecosystems [27].

The spatial sector is characterised by a complex system of different value chains. The transition to a circular economy within the construction and real estate sector requires optimising this chain from the source [30]. This not only concerns spatial and technical aspects, but mainly requires organisational and institutional changes and other processes in the design of the built environment. There are no new steps at the financial, administrative or organisational level to implement this structurally [31]. Circular construction starts with the design of a building, but also involves the associated collaboration and knowledge sharing. A subsequent life cycle of buildings, building elements, products and materials must be part of the design process [32]. This means that information must be made available in the long term and the working methods of the chain partners in the various stages of life must be coordinated. Making this information accessible to the actors involved plays an important role in this, so that sources can be used locally [33].

Existing instruments for assessing the environmental impact and sustainability aspects (such as Building Research Establishment Environmental Assessment Method (BREAAM), Life Cycle Analysis (LCA), ECO Cost) are partly in line with the principles of circularity and can be used as a basis for better specifying circularity requirements. However, these tools need to be further developed. These instruments can also be integrated with Building Information Management (BIM) [27]. 3D models of areas can serve as a framework for linking spatial information to data from a life cycle analysis or materials passport. In this way, data at different scale levels can be made transparent and can be related to each other-such as raw material flows at the area level but also within a building —and policy regarding the various raw material flows can be effectively coordinated [9].

Circularity not only has a physical side. Stakeholder interests and the way in which the actors involved make agreements with each other influence the overall process. Van Splunter [9] distinguishes between three groups of actors: Suppliers and producers influence the use and choice of raw materials. Designers and construction companies make product choices in the design process and determine which materials are added in the construction process. Clients, developers, investors and governments influence the first two groups through their commissioning, tender specifications and forms of contract, or through legislation.

Recent studies [20,34-36] by Wientjes, Potemans, Van Haagen and Castelein show that there are also various strategies in the spatial sector that are suitable for circular tendering or contracting. Pauliuk [16] criticises the fact that the monitoring of the implementation of circular strategies remains vague for the time being. Clients or organisations are responsible for choosing the right indicators and each determines their own standard for circularity. Companies are not structurally involved in circularity and governments, as clients do not take the lead enough to create professional preconditions and set circularity requirements $[27,37]$. The available instruments are insufficiently applied and, on the organisational side, instruments and processes are less developed [2]. 


\subsection{Sustainability Visions in Campus Development}

The subject of sustainability has received increasing attention in university research and educational institutions in recent years [38]. Sustainability aspects are becoming an important topic in many campus projects. Not only in terms of technical innovation [39], but also in terms of influencing behaviour, active sustainability policy on campus plays a special role in society. In the pursuit of a sustainable society, in the future many of the current students will also influence other people or organisations outside the campus through their decisions [40].

On the strategic, physical, financial and functional levels, campus management has increasingly changed into area development in recent years. However, the campus should not only be seen as a city, but also jointly with the city [41-43]. In terms of new strategies for sustainability, the campus offers itself as an ideal testing ground for the development and implementation of social and technological innovation, enabling universities to expand their innovation potential both inside and outside the campus walls [44]. The tasks of campus management have become increasingly complex over the years; changing structures in funding and rapidly changing themes in research require increasingly flexible housing [45], but university organisations structurally lack the money to invest in the development of their campuses [42]. Economical use of square metres contributes to sustainability goals and reduces the risk of future vacancy. Reducing the ecological footprint is also a strategic choice [46], but policy for more intensive use of space instead of building more calls for a different way of thinking. This requires sharing and multifunctional use of space on the campus and meeting peak demand through the use of temporary facilities. Relating the use of space to activities instead of allocating space to regular individual users can be a solution for making more efficient use of the available square metres [45].

More and more universities see a 'green campus' and achieving environmental objectives, such as reducing $\mathrm{CO}_{2}$ emissions or limiting the ecological footprint, as important goals within campus management. Existing buildings are used in different ways [42]. Various European universities have now set up Green Offices or appointed a sustainability programme manager as a point of contact with expertise in the field of sustainability [40]. However, Ávila et al. [44] pointed out that changes in the organisation of a university are not easy. Previous research [38] has shown that sustainability objectives in campus policy in general are too fragmented and are not systematically integrated and coordinated within the organisation. Despite the increasing urgency to consider sustainable development as part of their activities, many university organisations remain reluctant in reviewing their own business models. In particular, the investments required are often regarded as a barrier, while the benefits in terms of both environmental and economic performance are not sufficiently recognised [44]. The lack of support from university management and willingness among policy makers prove to be among the main obstacles [44].

\subsection{Knowledge Gap}

Global population growth (The global population has quadrupled in the last 100 years and will cross the nine billion mark by 2050) [47] and increasing prosperity are leading to an increasing demand for raw materials worldwide [48]. The circular economy is seen as an economic system that strives to use resources in a smart way and to preserve their value as much as possible. Sustainable structuring of the built environment and limiting our ecological footprint are becoming increasingly important to enable us to live a prosperous life on a healthy planet in the future. The spatial sector can contribute to reducing ecological footprints, but the circular economy requires an integrated approach that goes beyond the level of a building. Spatial projects are characterised by a high degree of complexity. By making connections between the various spatial scale levels, this study is looking for a system at a higher abstraction level for a structural circular approach in area development.

From the literature review, it is concluded that a gap exists in circularity in campus development. Universities and other educational institutions recognise the societal importance of sustainability issues and are increasingly focusing on them in their education and research programmes. This is often independent of the objectives for the development of their own campus $[40,44]$. Previous research 
shows that universities around the world, in different geographical regions, encounter similar obstacles to sustainable innovation on campus [44]. So far, few projects have been realised in campus or area development in which circularity is a determining factor. There is no systematic overview available of implementation strategies for the principles of a circular economy in area development or campus development. A framework that shows the connections between different dimensions and scale levels in the campus area is needed to provide CE implementation in campus development.

\section{Circularity Strategies}

\subsection{Systems Thinking and Life Cycles}

Systems thinking [16], synergy effects and closing cycles [15] involving the various life cycles in the area are important approaches to be able to apply the principles of circularity in area development processes. Since the 1950s, increasing interdependence in the world has led to new academic trends around complexity theories and systems thinking. It is recognised that new technologies alone will not solve our major sustainability issues. In systemic innovation, the social context changes simultaneously with the development of new knowledge and technology, and new ways of thinking, organising and acting arise in the context of the innovation [49]. Each system has a boundary and is characterised by a structure and a process, but also by the interaction between the system and the environment, the input and output. Systems thinking looks at both the bigger picture and the individual components [50]. In order to achieve synergistic effects, it is relevant to understand how components influence each other within the framework of the whole [12]. Involving the various life phases or life cycles and closing raw material chains are central strategies of the circular economy based on the principle of keeping a raw material in a cycle as long as possible, thereby limiting the loss of its value [5].

Whereas the initiatory and development phases of area development processes [51] (Figure 1) primarily involve intangible factors, such as policy and decision-making, more physical aspects, such as raw material flows, play a role during the implementation, use and management phases. At the end of a usage phase, it can be decided to redevelop and transform or reuse an area or building as a whole. This involves the process being restarted from the initiatory phase onwards [51]. Such choices affect the flows of raw materials and the input and output of the system. At the end of the life phase, these are extracted from the system, added as recycled materials or reused as building components.
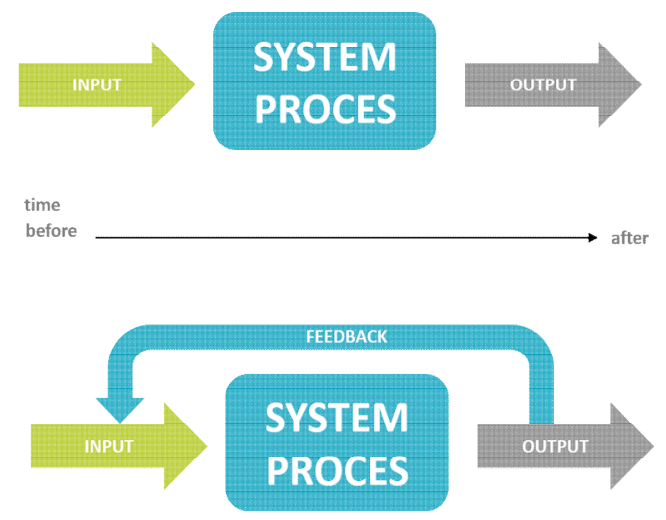

(a)

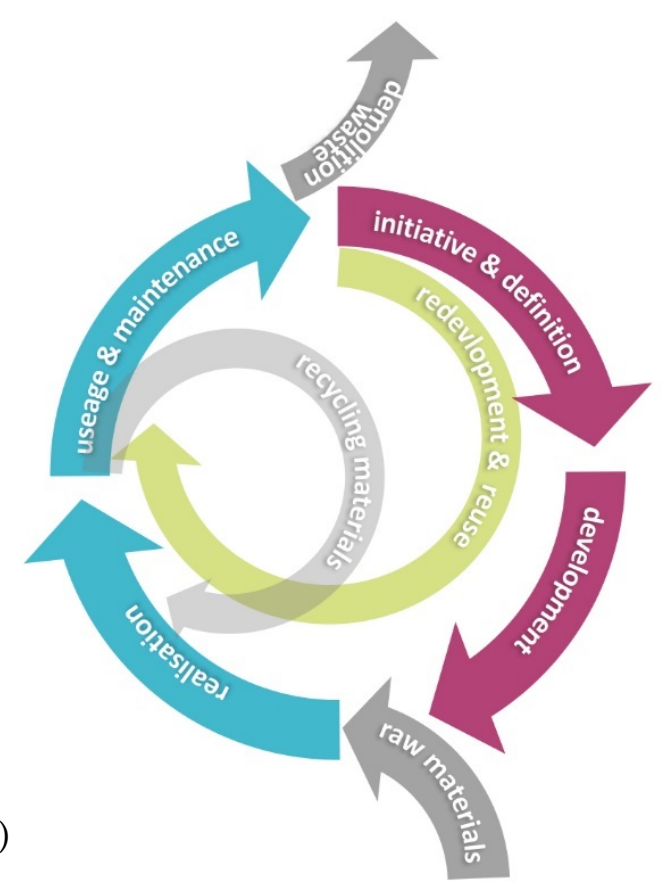

(b)

Figure 1. (a) System thinking; (b) life cycles in area and real estate development. 


\subsection{Dimensions in Campus Development}

Circularity in campus development can be viewed from different angles. The campus is understood as a 'system' and seen as a suitable testing ground for the application of circular principles. By looking beyond the boundaries of a building and involving resources and flows at the area level, the extent to which transformation and development processes on the campus are in line with the principles of circularity can be mapped out. Campus development is regarded as a specific organisational form in area development. According to the Glaser, Karssenberg, Laven, Teeffelen and Hoff [52] model, area development is determined by three categories: use (software), built environment (hardware) and management (orgware). The urban metabolism establishes a close link between the quality of a specific area and the inflow and outflow of the system. According to Tjallingii [25], the management of flows depends on the actors involved, and the three elements 'areas', 'flows' and 'actors' cannot be seen in isolation [24]. A research model has been developed to analyse the applicability of the principles of circularity in the campus system, based on the different dimensions of campus development. The four dimensions of 'organisation', 'use \& function', 'spatial scale levels' and 'flows \& materials' were used (Figure 2) for the theoretical analysis.

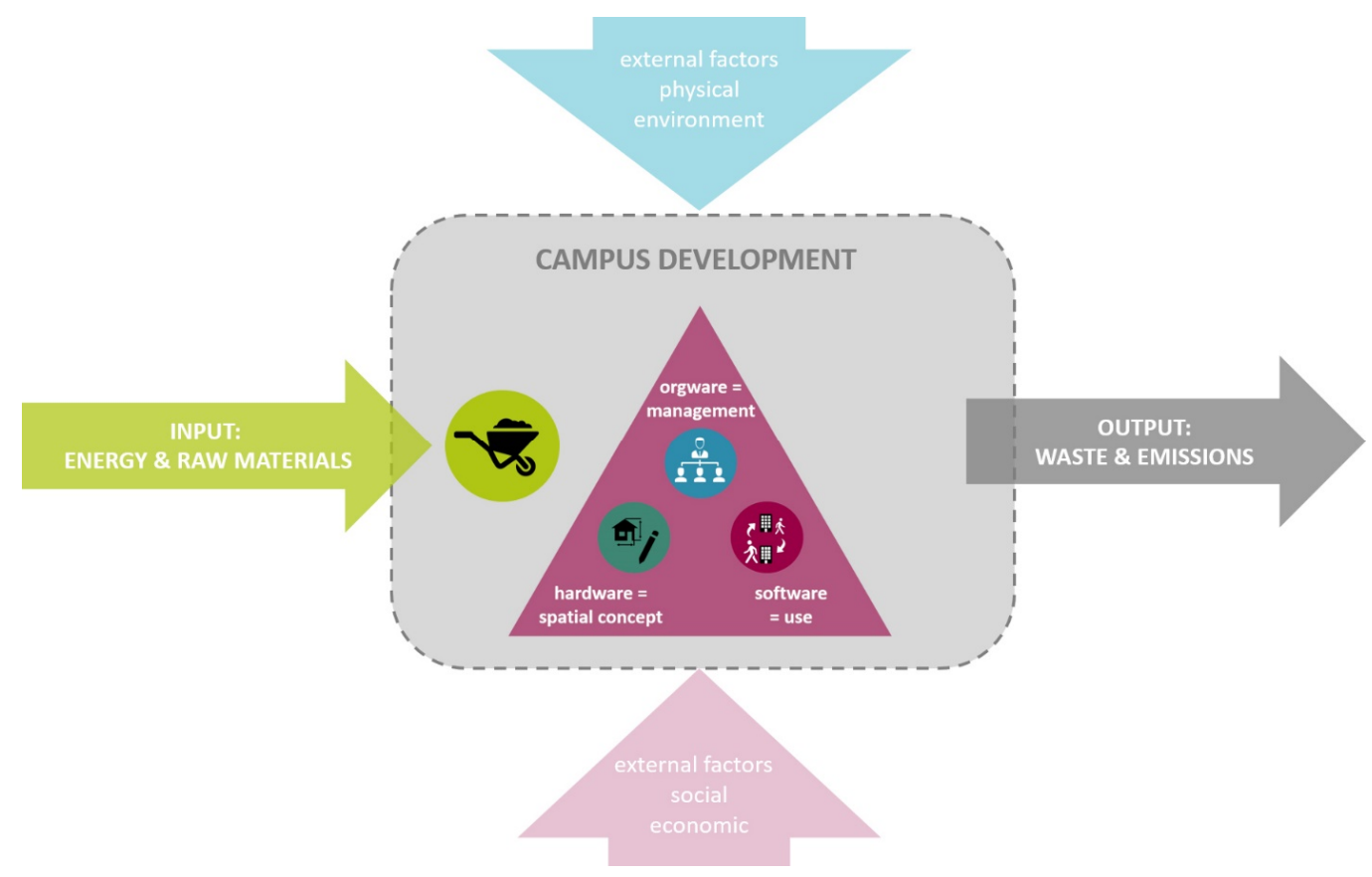

Figure 2. Research model with campus development as a system (own figure, based on various models from urban metabolism and area development).

Area development involves complex processes with a wide variety of stakeholders and actors. Area development processes are influenced by power relations, interaction and cooperation between the various actors [51]. Relationships between parties and actors are not only technological in nature, but also have a social character and are part of a complex network [2]. Ideally, an integrated area vision or real estate strategy should cover all phases and cycles of life. In the various life phases, different actors are again involved, which influence each other mutually through their decisions and actions (Figures 1 and 3). There is a complex network of parties and stakeholders involved in each phase of the development process. These have different goals and interests and each have their own strategies. Decision-making processes in networks are characterised by a system of mutual dependence and interdependence between the various actors [53]. Network management is a strategic tool to structure a complex field of action. The ability to link the various factors and elements is an influential factor for the success and task of process management $[51,54]$. The starting point is the interactions between 
parties, not the objectives of the individual actors [55]. Instead of a desire to achieve predefined results, adaptive capacity is the main requirement for managing the process $[56,57]$.

\section{Dimension organisation \& process}

(a)
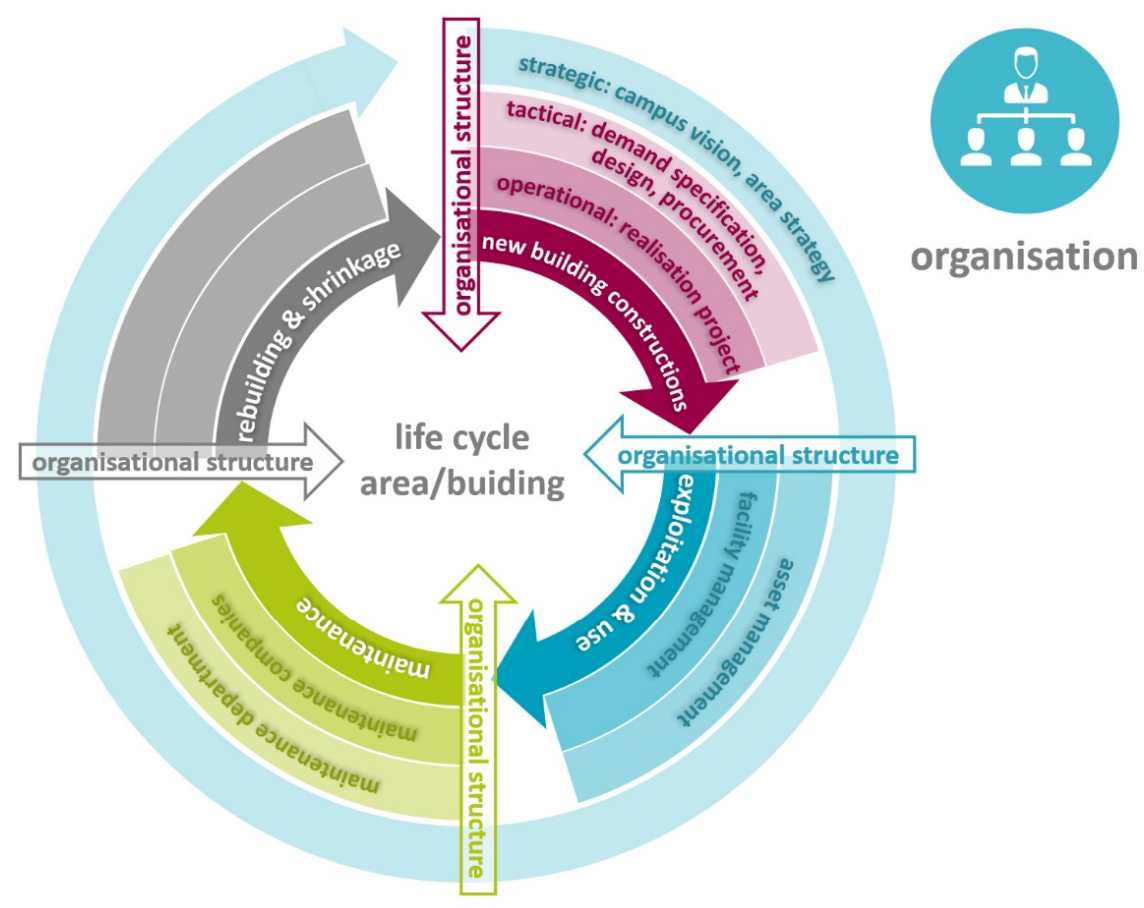

(b)
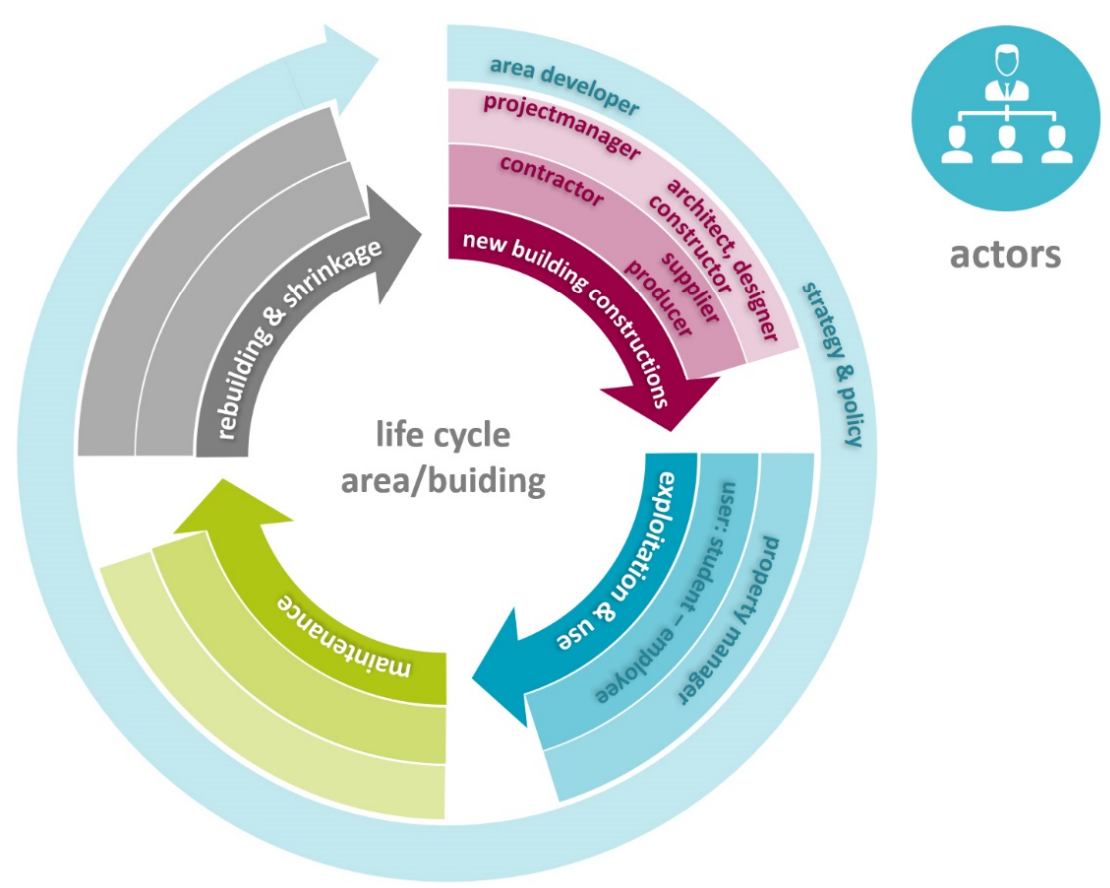

Figure 3. Dimension organisation \& process: (a) Organisational structure and development processes: Campus organizations are usually hierarchically structured line organizations with different layers: The strategic level, which focuses on setting strategic goals and policies, the tactical level with the task of setting up processes and steering the realization of goals and the operational level, responsible for the execution of goals. (b) Actors: Within the organisation, different departments or sometimes external parties are involved in the different processes within the campus development for each life cycle phase. 
Area development manifests itself through spatial changes in different areas, which are mutually correlated and are part of a city or region [51]. Apart from housing a university organisation, a campus also has a physical side. The spatial dimension is characterised by different levels of scale, which cannot be seen separately from one another. The spatial scale levels are often related to different functions such as the campus as a whole being a carrier for transport and underground infrastructure. In his approach, Brand [58] distinguished six different layers of a building, with a different life cycle each time for the area, the outer structure, the shell, the installation, the interior space and the layout. The separation of the various layers concerns not only the physical and technical components, but also the functional and economic interests and responsibilities [59]. By relating flows on campus to levels of scale and presenting them in cohesion, insights are sought for how chains can be closed (Figures 4-6). In some cases, local factors play an important role when it comes to closing cycles, while in other situations, optimisation can only be achieved on a larger scale [33].

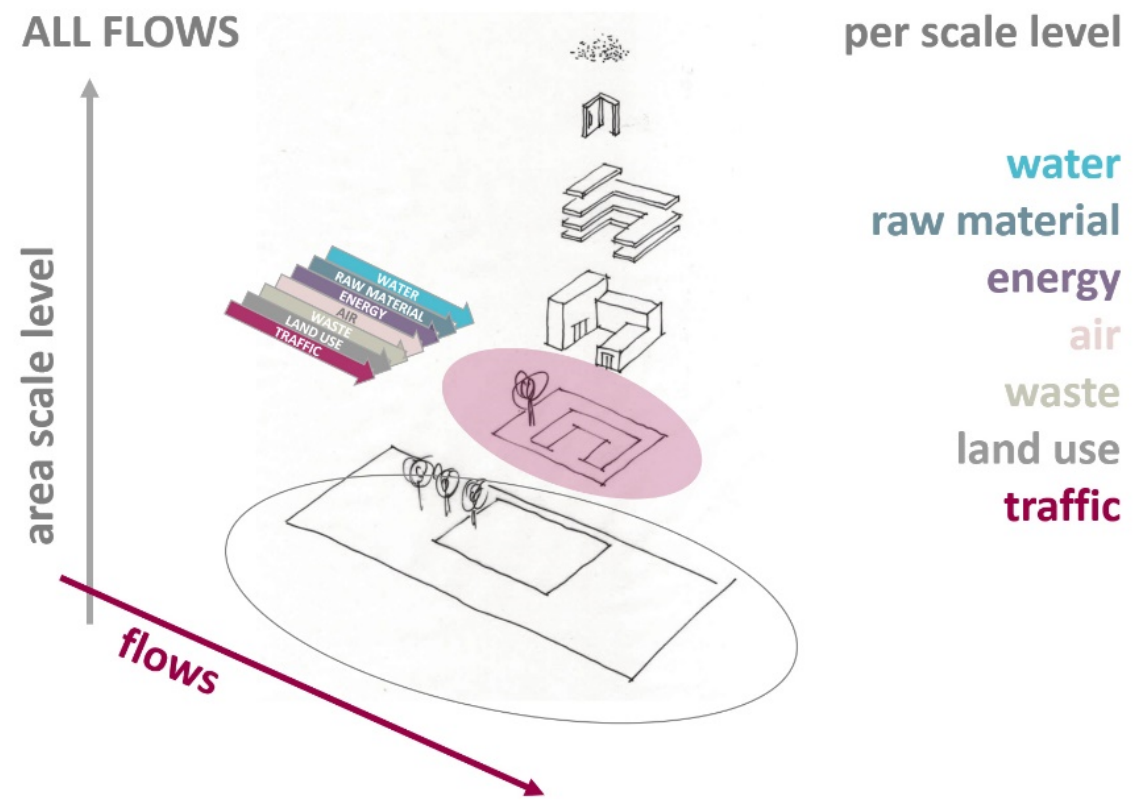

Figure 4. Relationship between all flows and one level of scale in the area.

In the theoretical framework, models from the area development are involved in order to be able to interpret circular principles in campus development. The research model (Figure 2) establishes connections between the different dimensions. The complex relationships between flows and levels of scale, principles of circularity, development processes and relevant actors are mapped out. The comparative analysis forms a theoretical approach to filtering factors and makes patterns visible: per scale level, different processes in campus development have an impact on the application of circular principles. The parties involved, such as the client, user, developer, manager, designer, contractor or producer, each have a different degree of influence by the choices they can make, depending on their role and the phase in the process (life cycle).

Depending on the scale level in the area, the strategies in the policy and system choices in the development process are decisive, or the choices of a producer in the production process of building materials have more influence on the degree of circularity. In order to apply circularity principles consistently, the different levels, phases and factors must be systematically linked to and weighed against each other for the whole life cycle.

Making the structures and connections transparent is an important condition in this respect. This applies not only to the construction chain, but the various actors within a campus organisation must also be involved. Intangible factors and processes at the organisational level, such as tendering policy and design choices, have a major influence on the applicability of circular principles. Requirements 
and criteria must be systematically specified and consistently applied in all development processes, especially at each level of scale and life phase, in order to achieve circularity in the spatial sector.

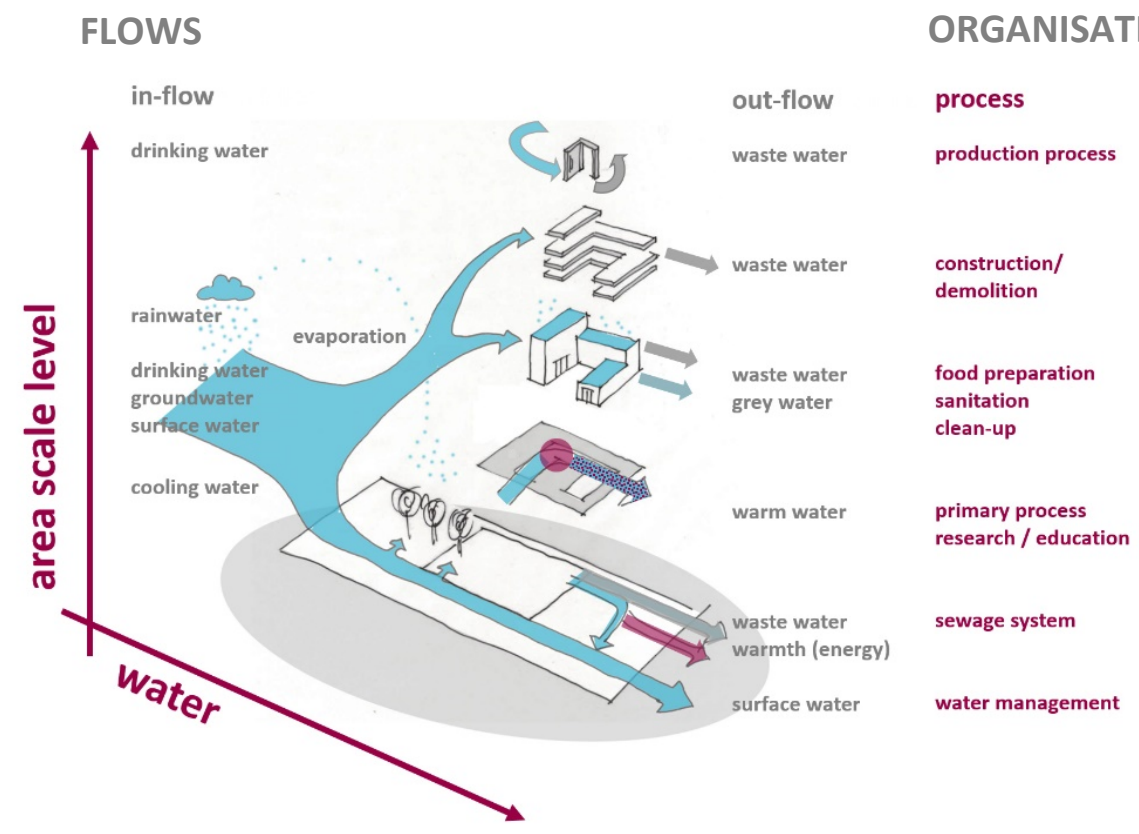

Figure 5. Example water-relationship between scale level of area, water flow and organisation (process).

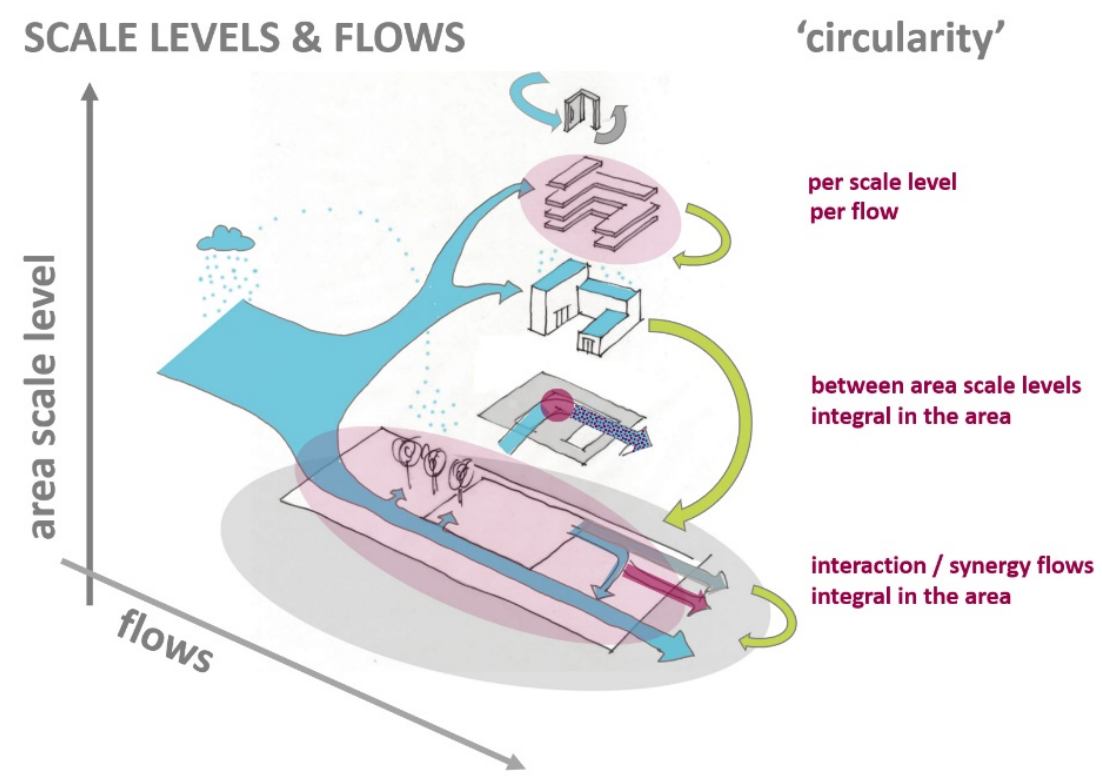

Figure 6. Closing cycles in relation to flows and scale areas: Cycles can be closed per flow or per scale level, but circularity can also be achieved between the different scale levels. In addition, an interaction can occur between different streams, per scale level or integrally in the area.

\subsection{Practical Explorations on Campus}

The subject of circularity is on the universities' agendas. The theoretical framework was verified and validated in 13 interviews with various stakeholder groups. Based on the theoretical analysis, interview questions were formulated to investigate how the circularity aspect is interpreted within the framework of the campus developments. The interviews were conducted among employees involved in sustainability, procurement and area development at six Dutch universities. Topics included circularity, sustainability and the four dimensions of campus development. 
The first series of interviews with developers as a specific group of stakeholders led to new insights. These insights were used in the second series of interviews with different types of stakeholders. The second series of interviews was more broadly focused on achieving sustainability objectives, circular approach and policy on campus and was conducted with sustainability programme managers and procurement and external advisors. Questions asked are like: To what extent does sustainability or circularity play a role on the campus (vision) or in the specific project? What then is the focus-such as materials and flows, system choices, reuse? Where does the question of circularity come from-own initiative/management/designer/or? Where is the biggest challenge concerning circular projects? What are the issues? The questions were formulated and the interviews held in Dutch language. The original questionnaire can be found as an appendix (Figure S1).

The result is that circularity is mainly seen as a means to achieve sustainability objectives. However, in campus development, circularity is experienced as a complex theme. There is no common thread to translate the sustainability objectives into concrete requirements at the tactical and operational level. The ambitions differ; initiatives arise mainly at the project level and are supported by individuals. Because organisations are unable to define their sustainability ambitions and set priorities in terms of circularity, it is difficult for project managers to translate the objectives into concrete requirements. Despite the formulated sustainability ambitions, principles of circularity are not structurally applied by Dutch universities. There is no common thread in the complex subject: The policy for internal organisational processes is insufficiently coordinated by the various departments. No integral strategy is formulated for circularity. The aim is to retain existing policy frameworks, processes and instruments without investigating whether it is useful to maintain them. No conscious links are made between development projects at the area level; circular objectives focus mainly on the building level, energy or waste flows.

\section{Results}

\subsection{Framework for a Circular Campus: Systems Thinking as a Starting Point}

The research results confirm the need for more integrated policies for the various departments and processes in order to achieve circular objectives. The insights from the theoretical research and interviews have been translated into a more generic approach to campus development. It is remarkable that concepts for circularity focus mainly on technological questions. In order to be able to close cycles and use synergy effects, the various scales and layers within the (campus) organisation are just as important for circular area development. In a complex network with many actors, divergent interests and specialization of processes, the concept of circularity requires system thinking and network management. Making connections between the various spatial scales is another important aspect. Intangible factors and processes at the organisational level, such as procurement policy and design choices, also have a major influence on the applicability of circular principles. Circular economy in area development concerns a cultural change that cannot be achieved by systematically rolling out objectives from above.

The 'circular campus framework' shows the relevant process steps in order to apply the principles of circularity in a systematic way. By making the coherence transparent, the framework brings structure to a complex theme and offers the possibility to get a grip on the subject based on the four dimensions. The integration of the dimensions of organisation, spatial scale levels, flows and use is an important aspect of this. The research shows that these dimensions are closely interrelated and influence each other. Going through a linear step-by-step plan with a start and an end point seems insufficient to achieve the intended results. In the conceptual model, systems thinking is used as an essential approach to circularity and the campus is considered to be a system. The different dimensions affect this system and therefore also the application of circular principles. This makes systems thinking the logical starting point for the implementation of circular principles on campus. 
The complexity and breadth of the concept of 'the circular economy' presents a major challenge for organisations to apply circular principles systematically as well, even though different methods and tools are available. Complexity occurs when a large number of actors or factors influence each other. 'Wicked problems' or unstructured problems are a recurring topic in area development $[60,61]$. Some concepts for network management in area development assume that increasing complexity can actually offer new perspectives. An overly sharp problem delineation in a process can then be dysfunctional, because the different actors have different perceptions of the problem. By formulating a problem broadly, different parties can contribute their interests [53,61-64].

Strategic innovation in the field of circularity requires continuous interaction in a complex network of internal and external actors. Changes take place at several points simultaneously in an iterative process, in which all relevant stakeholders must be involved. Depending on the perspective, there are different aspects and measures that influence each other. The dialogue between the parties concerned remains essential. By exchanging knowledge about issues and exploring new possibilities, the policy, work processes and responsibilities of departments are gradually developed.

\subsection{Integral Policy at Strategic Level}

On the one hand, the framework moves in the field of tension between integral policy at the strategic level (Figure 7) and, on the other hand, in translating objectives and making criteria specific at the tactical and operational level. Coordination of integral policy in the area of circularity is essential in order to prevent each department from formulating its own partial policy which is not consistent with the others'. Involving all departments in the development process and throughout the life cycle can create a consistent approach to circularity. This concerns the process side in the same way as the physical dimensions. Policy choices of the various departments affect the dimensions in different ways and need to be constantly adjusted in a dynamic process. A strategy for circular campus development must safeguard this coherence. The framework shows the mutual dependencies in a network system with different nodes (Figure 8). This not only concerns internal stakeholders within the campus organisation: A second axis in the field of tension concerns the relationship between internal and external parties and the method of working together. By asking clear questions, the client can stimulate the market without prescribing solutions. Being open to a different way of working and contractual arrangements are part of this. Methodologies for this already exist, but should be linked to circularity objectives.

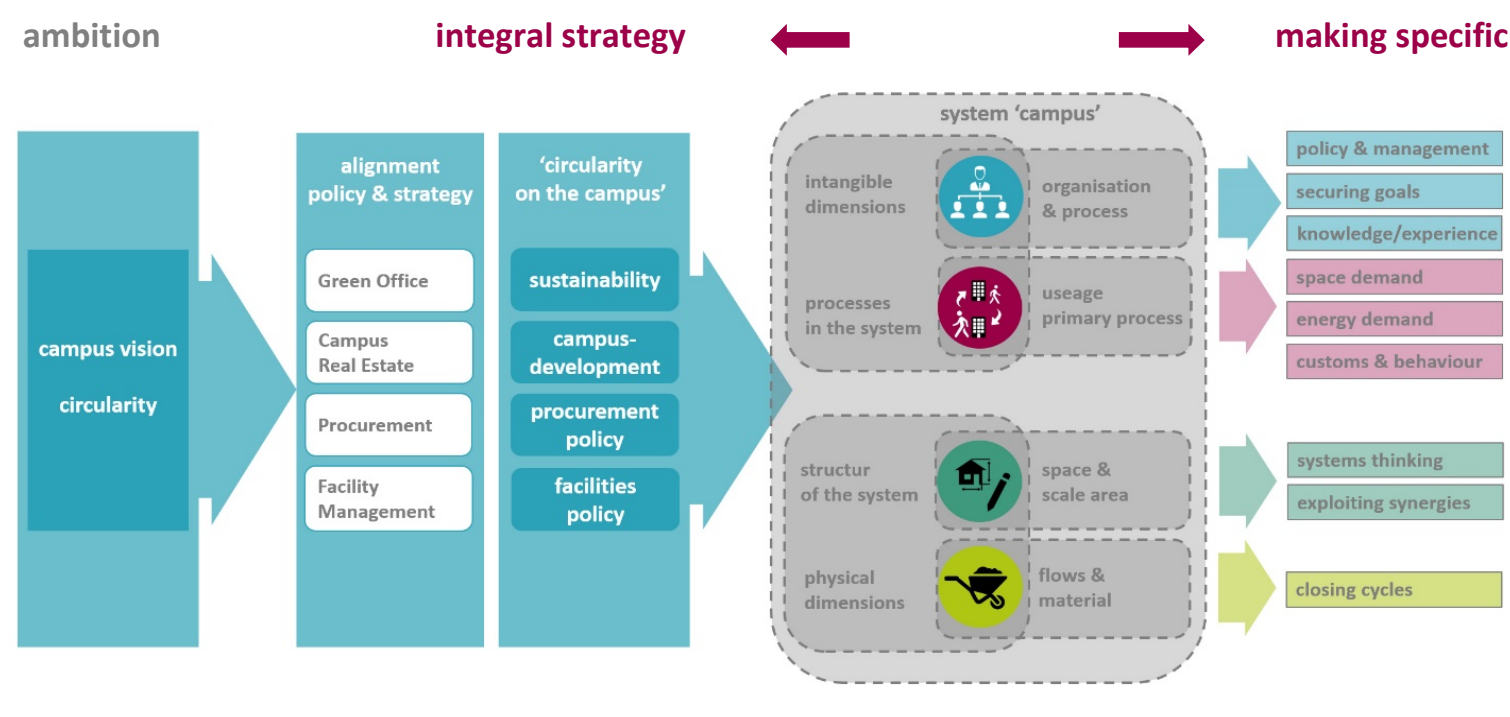

strategic

tactical/operational

Figure 7. Field of tension between integral policy and making criteria specific for the tactical and operational level. 


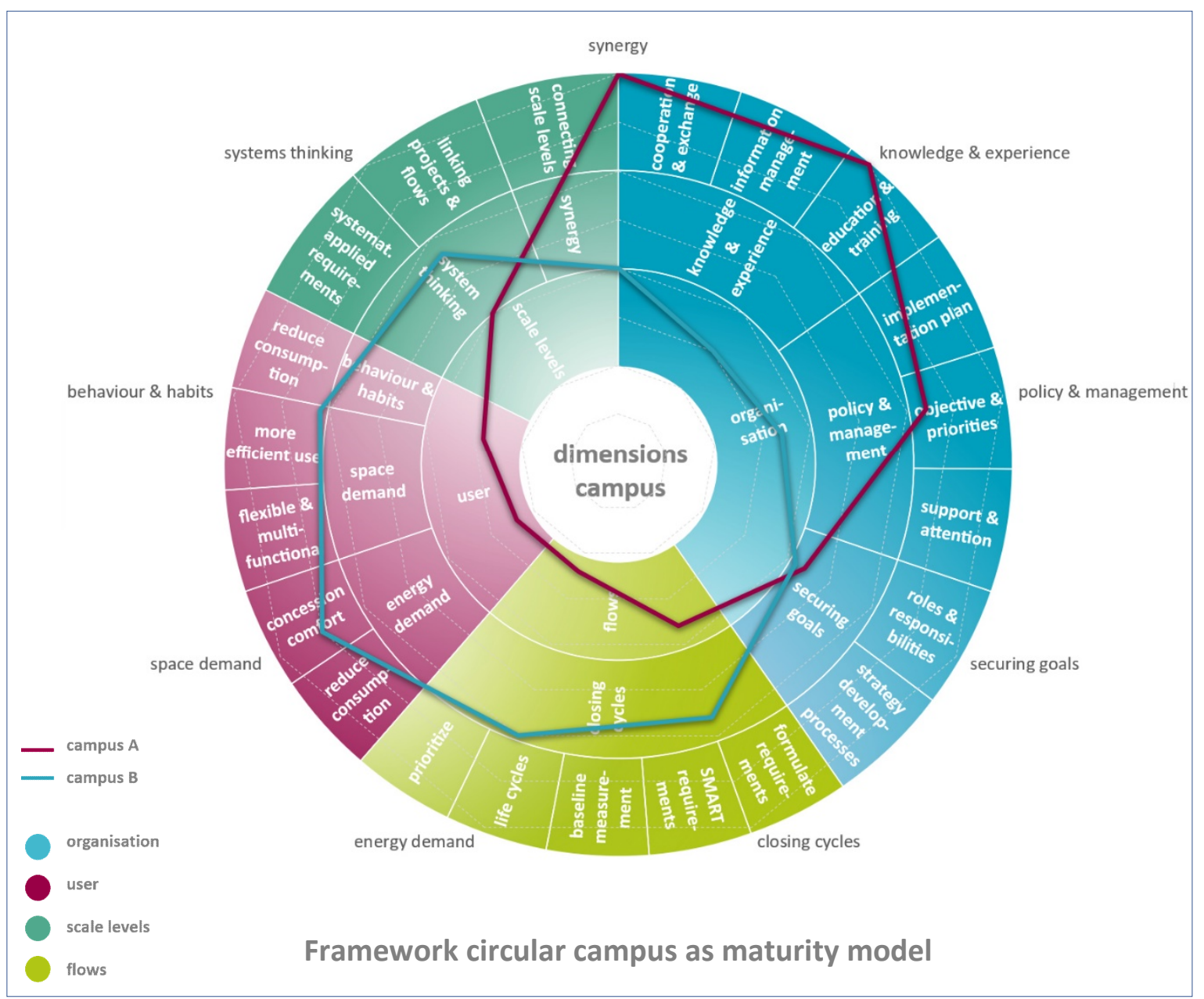

Figure 8. Framework for a circular campus as a maturity model with a fictitious example of two campuses. The framework cannot be seen as a blueprint. The starting point must be determined on the basis of a baseline measurement for the specific situation of a campus. Similar to a maturity model, the progress can be visualized in a coherent structure.

\subsection{Tactical and Operational Level Specification}

In addition to consistent policy at the strategic level, priorities and clear substantive objectives are required for the tactical and operational level. To this end, process agreements must be made at each scale level and concrete criteria must be determined for making the relevant flows circular (Figure 7). By defining a scope and gradually implementing it in terms of content, the complexity is reduced and the subject is clearer. For each dimension, various measures can contribute to putting circular ambitions into practice. Ensuring the coherence between the dimension is also essential at the tactical and operational level (Figure 8).

The systematics of the framework aim to make the underlying connections and structures visible. A clear scope can serve as a starting point for concrete substantive objectives and setting the necessary priorities. By linking thematic areas of attention on the campus to principles of circularity, a storyline is created and the subject becomes tangible for the various parties involved within the organisation. A pilot scheme on the campus such as a 'living lab circular campus' can play an important role in this if it goes beyond just a construction project and the various stakeholders are involved. Translating ambition into concrete content aspects makes the abstract subject of circularity more understandable and accessible. 


\section{Discussion and Conclusions}

\subsection{Discussion}

Circular economy in area development is still in its infancy. In practice, those involved are confronted with the complexity of the theme. As the analysis showed, not only technical system choices but also the structure and processes within the organization influence the implementation of circular principles. The interviews confirm a number of assumptions from the theoretical analysis. As far as we know, practical research on circular economy on campus has focused on separate scale levels or, for example, facility services, food and waste flows or the energy theme. Campus organisations are working on the subject of circularity, but after the first experimental phase there is still a need for better structure and standardisation, particularly when it comes to an area-based approach. By establishing a link between circular principles and the various dimensions of campus development, the study contributes to the development of a new structure.

This research is based on the theoretical analysis and on the experiences of 13 interviews on six university campuses in the Netherlands with a similar structure. This concerns technical universities, but also campuses without a focus on technology. It is suspected that this group is representative. Other forms of organisation, such as colleges of higher education or universities in other (European) countries, were not investigated. The literature study shows that similar subjects also play a role in non-Dutch educational organisations.

This paper aims to provide a framework for CE implementation in campus development. In all cases, the campuses investigated are clearly demarcated areas that are part of a city. Campuses with other spatial typologies such as a greenfield campus outside the city or a university with separate buildings that are fully integrated into the urban fabric were not specifically investigated. The question of whether circular principles can also be applied to the development and transformation of other areas has thus not yet been answered. The system boundary plays a role in the application of circular principles. The results of this study suggest that full integration into the structures of a city increase the complexity and number of actors and that other processes influence the system. The design of business parks with clearly defined spatial and organisational boundaries, on the other hand, is comparable to the campuses studied. Additional research, in which more and different types of area typologies, organisational and administrative units are investigated, can contribute to broadening and deepening the knowledge about the application possibilities of circularity in area development processes.

\subsection{Conclusions}

Circularity is an organisational issue, but concepts for circularity focus mainly on technological questions. A framework for practical applications is lacking in campus development and there is a need for a better system that involves the various levels of scale of the area. In a complex network with many actors, divergent interests and specialisation of processes, circularity requires systems thinking and network management. Intangible factors and processes at the organisational level, such as tendering policy and design choices, also have a major influence on the applicability of circular principles. The circular economy in area development concerns a culture change that cannot be achieved by systematically rolling out objectives from above. Without an integrated policy, holding on to existing frameworks and instruments can be an obstacle if they do not sufficiently correspond to the approaches of circularity. As long as there is no meta-level vision, solutions will continue to focus on individual projects or technical details, without an integrated approach for the campus.

The complexity of the circular economy concept and the limited experience with it pose a major challenge to campus organisations. The subject must be made more comprehensible and accessible to the various parties involved, so that concrete steps can be taken. A clear system with a clear scope helps to make the underlying connections and structures visible and to set the necessary priorities for substantive objectives. One conclusion of this study is that the complexity must be reduced, especially in the initial phase, for the tactical and operational level. 
Campus organisations want to get to work with circularity, but do not know exactly how to put it into practice. The expertise is limited and the substantive meaning of 'circular' is often not well thought-out. As a result, it remains unclear where the benefits lie and what the specific requirements should be. To ensure long-term circular objectives, integral policy and specific knowledge are required. Responsibilities and roles must be explicitly defined within the organisational structure. At the management level, the support base must be increased and the subject must structurally be given more priority in the various processes.

The universities have an important guiding role as a driver of circularity in the further development of instruments and processes. Although various instruments or certifications are available for sustainability aspects, they are not being applied sufficiently for circularity objectives. The circular development process requires a different way of thinking and working together in networks in the exchange of knowledge between client, designer, consultant, contractor and supplier. Exchange within an inter-university network could provide many valuable insights for implementation, but in practice, every campus reinvents the wheel.

\subsection{Follow-Up Study}

In all cases, the campuses studied are clearly demarcated areas that are part of a city. Additional research, in which more and different types of area typologies, organisational and administrative units are studied, can contribute to broadening and deepening the knowledge about the application possibilities of circularity in area development processes.

Existing methods for testing sustainability objectives or resource flows should be further developed into useful tools for testing circular aspects in area development. A combination of the resulting data with 3D building models and BIM can lead to new insights for the application of circular principles in area development and is a separate research theme in the field of information management. Measurement instruments and performance indicators which take circularity into account in an integral assessment of quality are lacking in campus development.

\subsection{Recommendations for a Circular Campus}

In order to be able to take steps towards an integrated strategy for circularity in campus development, the most important recommendations of the study are as follows:

1. Ensure a consistent policy and support from all departments by formulating an integral strategy for circularity. Make sure you also have an implementation plan.

2. Further develop the proposed system into a useful instrument by specifying substantive requirements and concrete objectives for the tactical and operational level.

3. Reduce complexity and make the subject of circularity accessible and understandable. Set clear priorities in the initial phase.

4. Let go of the automatism of existing frameworks and create space and flexibility for a different approach in the development process.

5. Think and work more in network contexts. To be able to close cycles at the local level, consciously establish links between development projects on campus at different scales and in different life cycles.

Supplementary Materials: The following are available online at http:/ /www.mdpi.com/2071-1050/11/3/627/s1, Figure S1: New dimensions for circularity on campus-appendix questionnaire 190112, Table S1: New dimensions for circularity on campus-appendix analysis 190112.

Author Contributions: Conceptualization, B.H., S.N. and L.V.; methodology, B.H., S.N. and L.V.; validation, B.H. and L.V.; formal analysis, B.H.; investigation, B.H.; resources, B.H.; writing-original draft preparation, B.H.; writing-review and editing, S.N and L.V.; visualization, B.H.; supervision, S.N and L.V.; project administration, B.H.

Funding: This research received no external funding. 
Conflicts of Interest: The authors declare no conflict of interest.

\section{References}

1. Geissdoerfer, M.; Savaget, P.; Bocken, N.M.P.; Hultink, E.J. The Circular Economy-A new sustainability paradigm? J. Clean. Prod. 2017, 143, 757-768. [CrossRef]

2. Leising, E.; Quist, J.; Bocken, N. Circular Economy in the building sector: Three cases and a collaboration tool. J. Clean. Prod. 2018, 176, 976-989. [CrossRef]

3. Kirchherr, J.; Reike, D.; Hekkert, M. Conceptualizing the circular economy: An analysis of 114 definitions. Resour. Conserv. Recycl. 2017, 127, 221-232. [CrossRef]

4. Ghisellini, P.; Cialani, C.; Ulgiati, S. A review on circular economy: The expected transition to a balanced interplay of environmental and economic systems. J. Clean. Prod. 2016, 114, 11-32. [CrossRef]

5. Jonker, J.; Stegeman, H.; Faber, N. De Circulaire Economie-Denkbeelden, ontwikkelingen en business modellen. Work. Pap. 2018. [CrossRef]

6. Pomponi, F.; Moncaster, A. Circular economy for the built environment: A research framework. J. Clean. Prod. 2017, 143, 710-718. [CrossRef]

7. Braungart, M.; McDonough, W. Die Nächste Industrielle Revolution-Die Cradle to Cradle-Community, 3rd ed.; Europäische Verlagsanstalt: Hamburg, Germany, 2011; ISBN 9783863930059.

8. Ganzevles, J.; Potting, J.; Hanemaaijer, A. Evaluatie Green Deals Circulaire Economie; PBL Planbureau voor de Leefomgeving: Den Haag, The Netherlands, 2016.

9. Van Splunter, M. Circulair Bouwen Slopen: Ketenverkenning van de Bouw-En Sloopsector Cirkelregio Utrecht; Utrecht Sustainability Institute: Utrecht, The Netherlands, 2016.

10. Meadows, D.H.M. The Limits to Growth. A Report for the Club of Rome's Project on the Predicament of Mankind; Universe Books: New York, NY, USA, 1972.

11. Braungart, M.; McDonough, W. Cradle to Cradle: Remaking the Way We Make Things; North Point Press: New York, NY, USA, 2002; ISBN 9780865475878.

12. Ellen MacArthur Foundation. Towards the Circular Economy (Report); Ellen MacArthur Foundation: Cowes, UK, 2013; pp. 1-96.

13. Brundtland, G.H. Our Common Future: Report of the World Commission on Environment and Development. Unit. Nations Comm. 1987, 4, 300. [CrossRef]

14. Ruiz-Real, J.L.; Uribe-Toril, J.; De Pablo Valenciano, J.; Gázquez-Abad, J.C. Worldwide Research on Circular Economy and Environment: A Bibliometric Analysis. Int. J. Environ. Res. Public Health 2018, 15, 2699. [CrossRef] [PubMed]

15. Bocken, N.M.P.; de Pauw, I.; Bakker, C.; van der Grinten, B. Product design and business model strategies for a circular economy. J. Ind. Prod. Eng. 2016, 33, 308-320. [CrossRef]

16. Pauliuk, S. Critical appraisal of the circular economy standard BS 8001:2017 and a dashboard of quantitative system indicators for its implementation in organizations. Resour. Conserv. Recycl. 2018, 129, 81-92. [CrossRef]

17. Preston, F. A Global Redesign? Shaping the Circular Economy. Energy Environ. Resour. Gov. 2012, 1-20. [CrossRef]

18. Von Bertalanffy, L. General System Theory: Foundations, Development, Applications; George Braziller: New York, NY, USA, 1968.

19. De Zeeuw, F. Zo Werkt Gebiedsontwikkeling; Delft University of Technology, Praktijkleerstoel Gebiedsontwikkeling: Delft, The Netherlands, 2017.

20. Wientjes, R. Circulaire Economie Binnen de Ruimtelijke Ordening in Westas; Saxion Hogeschool: Deventer, The Netherlands, 2015; Available online: http:/ /www.kennislabvoorurbanisme.nl/wp-content/uploads / Circulaire-Stad.pdf (accessed on 10 December 2017).

21. Potting, J.; Hekkert, M.; Worrell, E.; Hanemaaijer, A. Circular Economy: Measuring Innovation in the Product Chain-Policy Report (2544); PBL Netherlands Environmental Assessment Agency: The Hague, The Netherlands, 2017.

22. Kennedy, C.; Pincetl, S.; Bunje, P. The study of urban metabolism and its applications to urban planning and design. Environ. Pollut. 2011, 159, 1965-1973. [CrossRef] [PubMed] 
23. Boomen, T.; van den Frijters, E.; van Assen, S.; Broekman, M. (Eds.) Urban Challenges, Resilient Solutions. Design Thinking for the Future of Urban Regions; Trancity-Valiz: Amersfoort, The Netherlands, 2017; ISBN 9789492095336.

24. Jelier, W.P.C. Het Concept Stedelijk Metabolisme: Verkenning van Het Concept 'Stedelijk Metabolisme' Met Het oog op de Bruikbaarheid ervan voor Duurzame Stedelijke Ontwikkeling. Master's Thesis, Delft University of Technology, Delft, The Netherlands, 2011.

25. Tjallingii, S.P. Ecopolis: Strategies for Ecologically Sound Urban Development. Landscape and Urban Planning; Backhuys Publishers: Leiden, The Netherlands, 1995.

26. Rijksoverheid. Nederland Circulair in 2050. Government of The Netherlands. 2017. Available online: https: / / circulaireeconomienederland.nl/rijksbreed+programma+circulaire+economie/default.aspx (accessed on 3 March 2018).

27. Schut, E.; Crielaard, M.; Mesman, M. Beleidsverkenning circulaire economie in de bouw. Rijkswaterstaat, Rijksinstituut voor Volksgezondheid en Milieu, The Netherlands. 2015. Available online: https://www. rivm.nl/bibliotheek/rapporten/2015-0197.pdf (accessed on 3 March 2018).

28. Nederland Circulair. Meer dan helft alle grondstoffen verbruikt in bouwsector: Kansen voor circulair?-Nederland circulair. The Netherlands. 2016. Available online: https://www. circulairondernemen.nl/uitdagingen/meer-dan-helft-alle-grondstoffen-verbruikt-in-bouwsectorkansen-voor-circulair (accessed on 28 April 2018).

29. Transitieteam Circulaire Bouweconomie. Transitie-Agenda Circulaire Bouweconomie. Government of The Netherlands, 2018. Available online: https:/ / www.rijksoverheid.nl/documenten/rapporten/2018/01/15/ bijlage-4-transitieagenda-bouw (accessed on 14 March 2018).

30. Bastein, T.; Roelofs, E.; Rietveld, E.; Hoogendoorn, A. Kansen voor de Circulaire Economie in Nederland; TNO: Delft, The Netherlands, 2013; pp. 1-93. Available online: https://www.rijksoverheid.nl/documenten/ rapporten/2013/06/20/tno-rapport-kansen-voor-de-circulaire-economie-in-nederland (accessed on 3 March 2018).

31. Cramer, J. Strategische Verkenning 'Op weg Naar Cirkelregio Utrecht'; Utrecht Sustainability Institute: Utrecht, The Netherlands, 2015.

32. Bijleveld, M.M.; Bergsma, G.C.; Krutwagen, B.T.J.M.; Afman, M.A. Meten is Weten in de Nederlandse Bouw Milieu-Impacts van de Nederlandse Bouw-En Sloopactiviteiten in 2010; CE Delft/Bouwend Nederland: Delft, The Netherlands, 2015.

33. IABR. Stedelijk Metabolisme, Duurzame Ontwikkeling van Rotterdam; IABR: Rotterdam, The Netherlands, 2014.

34. Potemans, A. Modular Building in a Circular Economy. Master's Thesis, Delft University of Technology, Delft, The Netherlands, 2017.

35. Van Haagen, F.P.C. Circulair Aanbesteden-DNA-Match: Het Geheim Achter Een Spraakmakende Circulaire Aanbesteding. Master's Thesis, Delft University of Technology, Delft, The Netherlands, 2018.

36. Castelein, L. Circulair Contracteren: Een Onderzoek Naar De Huidige Mogelijkheden Voor Circulariteit in Bouwcontracten. Master's Thesis, Delft University of Technology, Delft, The Netherlands, 2018.

37. Ten Klooster, G. Op Weg Naar Circulair Bouwen en Slopen in Amersfoort; University of Twente: Enschede, The Netherlands, 2017; Volume 41, Available online: http:/ / research.economicboardutrecht.nl/sites/nl. economicboardutrecht.research/files/OpwegnaarcirculairbouwenenslopeninAmersfoort.pdf (accessed on 24 January 2018).

38. Lozano, R.; Ceulemans, K.; Alonso-Almeida, M.; Huisingh, D.; Lozano, F.J.; Waas, T.; Hugé, J. A review of commitment and implementation of sustainable development in higher education: Results from a worldwide survey. J. Clean. Prod. 2014, 108, 1-18. [CrossRef]

39. De Vries, J. Presteren Door Vastgoed, Onderzoek Naar De Gevolgen Van Vastgoedingrepen Voor De Prestatie Van Hogescholen. Ph.D. Thesis, Delft University of Technology, Delft, The Netherlands, 2007.

40. Verhoef, L.; Graamans, L.; Gioutsos, D.; Van Wijk, A.; Geraedts, J.; Hellinga, C. ShowHow: A Flexible, Structured Approach to Commit University Stakeholders to Sustainable Development. In Handbook of Theory and Practice of Sustainable Development in Higher Education; Filho, W.L., Azeiteiro, U.M., Molthan-Hill, F.A., Eds.; Springer: Berlin/Heidelberg, Germany, 2017; Volume 4, pp. 491-508. [CrossRef]

41. Den Heijer, A.C. Managing the University Campus: Information to Support Real Estate Decisions. Ph.D. Thesis, Delft University of Technology, Delft, The Netherlands, 2011. 
42. Curvelo Magdaniel, F. Technology Campuses and Cities: A Study on the Relation Between Innovation and the Built Environment at the Urban Area Level. Ph.D. Thesis, Delft University of Technology, Delft, The Netherlands, 2016.

43. Den Heijer, A.C.; Curvelo Magdaniel, F.T.J.C. The university campus as a knowledge city: Exploring models and strategic choices. Int. J. Knowl. Based Dev. 2012, 3, 283-304. [CrossRef]

44. Ávila, L.V.; Leal Filho, W.; Brandli, L.; Macgregor, C.J.; Molthan-Hill, P.; Özuyar, P.G.; Moreira, R.M. Barriers to innovation and sustainability at universities around the world. J. Clean. Prod. 2017, 164, 1268-1278. [CrossRef]

45. Den Heijer, A.C.; Arkesteijn, M.; de Jong, P.; de Bruyne, E. Campus NL-Investeren in de Toekomst (Report). Architecture, Management in the Built Environment; Delft University of Technology: Delft, The Netherlands, 2016; Available online: http:/ / www.vsnu.nl/files/documents/CampusNLdigitalversion(forwebsites).pdf (accessed on 4 January 2018).

46. Den Heijer, A.C. Campus Wordt Duurzame Kennisstad: Het Delen van Ruimte als Positieve Keuze (Journal Article); Delft University of Technology: Delft, The Netherlands, 2011; Available online: https: / / repository. tudelft.nl/islandora/object/uuid\%3Afb3b5dae-b452-4c37-8785-ca6fac75ee0b?collection=research (accessed on 21 February 2018).

47. Circulaireeconomienederland. Available online: https://www.circulaireeconomienederland.nl/default.aspx (accessed on 26 November 2018).

48. EEA. SOER 2015-The European Environment-State and Outlook 2015; European Environment Agency: Copenhagen, Denmark, 2015; Available online: https://www.eea.europa.eu/soer (accessed on 26 November 2018).

49. Loorbach, D.A. To Transition! Governance Panarchy in the New Transformation; Erasmus University Rotterdam: Rotterdam, The Netherlands, 2014; ISBN 978-90-822881-0-0.

50. De Graaf, R.S. Basisboek Systems Engineering in de Bouw: Een Methodische Totaalaanpak van Het Bouwproces; Brave New Books: Austin, TX, USA, 2014; Available online: https:/ / research.utwente.nl/en/publications / basisboek-systems-engineering-in-de-bouw (accessed on 10 May 2018).

51. Franzen, A.; Hobma, F.; de Jonge, H.; Wigmans, G. Management of Urban Development Processes. Governance, Design and Feasibility; Techne Press: Amsterdam, The Netherlands; Delft, The Netherlands, 2010; ISBN 9789085940296.

52. Glaser, M.; Karssenberg, H.; Laven, J.; van Teeffelen, J.; van't Hoff, M. The City at Eye Level. Lessons for Street Plinths; Eburon Academic Publishers: Delft, The Netherlands, 2016.

53. Teisman, G.; Gerrits, L. The Emergence of Complexity in the Art and Science of Governance. Complex. Gov. Netw. 2014, 1, 7-28. [CrossRef]

54. Klijn, E.H.; Steijn, B.; Edelenbos, J. The Impact of Network Management on Outcomes. Gov. Netw. Public Adm. 2010, 88, 1063-1082. [CrossRef]

55. Nelissen, N.; de Goede, P.; van Twist, M. Oog voor Openbaar Bestuur; Elsevier Overheid: The Hague, The Netherlands, 2004; ISBN 9059014987.

56. Daamen, T.A.; Verheul, W.J. Stedelijke ontwikkeling als een emergente adaptieve strategie. Bestuurswetenschappen 2014. [CrossRef]

57. Hopff, B. De Stad en de Campus (Essay); MCD Erasmus University Rotterdam: Rotterdam, The Netherlands, 2017.

58. Brand, S. How Buildings Learn: What Happens after They're Built; Viking Press: New York, NY, USA, 1994.

59. Zuidema, R. De Olifant Dendert Door de Circulaire Stad, 2nd ed.; Stichting BRIQS: Amsterdam, The Netherlands, 2017; ISBN 978-94-92383-67-9.

60. Nijhuis, S.; de Vries, J.; Noortman, A. Ontwerpend onderzoek. In Praktijkgericht Onderzoek in de Ruimtelijke Planvorming; Simons, W., van Dorp, D., Eds.; Methoden voor analyse en visievorming; Uitgeverij Landwerk: Wageningen, The Netherlands, 2017; pp. 256-283.

61. De Bruijn, H.; Ten Heuvelhof, E.; in't Veld, R. Een Nadere Positionering van de Procesbenadering. Procesmanagement. Over Procesontwerp en Besluitvorming, 4th ed.; Boom Uitgevers: Amsterdam, The Netherlands, 2012; ISBN 9789052619323.

62. Teisman, G. Publiek Management op de Grens van Chaos en Orde (Public Management on the Border of Chaos and Order); Erasmus University Rotterdam: Rotterdam, The Netherlands, 2005. 
63. Loorbach, D.A. Transition Management for Sustainable Development: A Prescriptive, Complexity-Based. Governance 2010, 23, 161-183. [CrossRef]

64. De Bruijn, J.A.; Ten Heuvelhof, E. Strategieën: Een vergelijking tussen projectmatige en procesmatige verandering. In Management in Netwerken; Boom Lemma Uitgevers: Utrecht, The Netherlands, 2007; pp. 75-109. ISBN 9789059310131. 